音声言語医学 $61 ： 230-236,2020$

原 著

\title{
失語症者における呼称課題条件と言語性保続の発生
}

\author{
玉置 円11 中村 光 $^{2)}$
}

要 旨: 本研究の目的は, 条件を統制した呼称課題を実施し, 失語症者の言語性保続減少の ための基礎データを得ることである。研究 1 では, 失語症者 22 名（男性 14 名, 女性 8 名）に 対し, 刺激項目 (絵カード) の意味カテゴリー (動物/道具), 色情報の有無 (白黒/カラー), 提示間隔（1 秒 $/ 10$ 秒）を操作した呼称課題を実施した。 その結果，保続の出現数に対しカテ ゴリー，およびカテゴリーと提示間隔の組み合わせが関連する可能性が示された。そこで研究 2 として, 提示間隔に 20 秒条件を加え, 刺激提示方法をより厳密に操作した呼称課題を失語 症者 28 名（男性 18 名, 女性 10 名）に実施した。 その結果, 動物カテゴリーに抒ける保続は 道具カテゴリーよりも高頻度で減衰しにくいことが確認された. 保続が多く出現する患者には, 非生物カテゴリーを中心とした訓練プログラムを立案することで, 保続を抑制して言語機能訓 練が提供できる可能性が示唆された.

索引用語：呼称, 言語性保続, 意味カテゴリー, 分散モデル, 意味属性

\section{Verbal Perseveration on Controlled Picture Naming Tasks in Aphasia}

\author{
Madoka Tamaoki ${ }^{1)}$ and Hikaru Nakamura ${ }^{2)}$
}

\begin{abstract}
The purpose of this study was to acquire basic data applicable to decreasing verbal perseveration in aphasia. We performed two picture naming tasks. In study 1 , the subjects were 22 patients with aphasia ( 14 males, 8 females). The naming task was conducted while controlling for the following three factors: semantic category (animals/tools), color information (black-and-white/color), and presentation interval (1 second/10 seconds). The results revealed a possibility that semantic category and the combination of semantic category and presentation interval are related to the occurrence of perseveration. In study 2, the subjects were 28 patients with aphasia (18 males, 10 females). The naming task was conducted while controlling for the semantic category (animals/tools) and the presentation interval, which was strictly managed (1 second/10 seconds/20 seconds). The results confirmed that perseverations in the animals category occurred more frequently and were maintained for longer times than those in the tools category. These findings suggest that items belonging to non-living categories, rather than living categories, might be useful for inhibiting the occurrence of perseverations during the treatment of aphasic patients.
\end{abstract}

元 倉敷平成病院リハビリテーション部 ${ }^{1)}$ ： ₹710-0826 岡山県倉敷市老松町 4-3-38

岡山県立大学保健福祉学部保健福祉学科 ${ }^{2)}$ : $=719-1197$ 岡山県総社市窪木 111

${ }^{1)}$ Formerly: Department of Rehabilitation, Kurashiki Heisei Hospital: 4-3-38 Oimatsucho, Kurashiki, Okayama 710-0826, Japan

${ }^{2)}$ Department of Health and Welfare Science, Okayama Prefectural University: 111 Kuboki, Soja, Okayama 719-1197, Japan

2019 年 8 月 26 日受稿 2019 年 11 月 18 日受理 
Key words: picture naming task, verbal perseveration, semantic category, distributed model, semantic feature

\section{はじめに}

保続とは Neisser（1895）によって,「以前の反応 の不適切な反復または持続」と定義されている1 のなかで言語性保続は，以前に発した言葉が本人の意 図に反して以降の発話機会に再度出現するものをい う。われわれは臨床現場において，言語性保続が会話 の妨げとなり，失語症者にとって大きな心理的負担に つながることを経験する.

先行研究に打ける言語性保続の発現機序仮説は, Martin $~^{2)}$ や Pilkington $~^{3)}$ が，(1)目標語や音の弱 い活性化が関連する，または(2)以前の語や音の残存活 性 (抑制過程障害) が関連すると指摘しているように, 活性化不足説と抑制不足説の 2 つに大別できる．前者 を主張する $\mathrm{Hirsh}^{4)}$ は，保続として出現する語は先行 する語のなかでも，特に目標語と意味的または音韻的 に関連するものが多いことを根拠として，目標語の語 彙や音韻の活性化に失敗し，すでに活性化した項目を 選択するため保続が出現すると述べている。また Corbett ら) $^{5)}$ は, 呼称課題においてヒントを提示する と誤答のなかの保続の比率が減少することを根拠に， 活性化の調整の困難さが保続に関係していると述べて いる，他方，後者を主張する Yamadori ${ }^{6)}$ は，先行す る語の全体だけでなく一部が出現することもあること を根拠に，抑制されていない無関係な記憶の痕跡が保 続に関係していると述べている。 また Albert ら7)も, 保続は短期記憶に保持されている，すでに表出した項 目の賦活を抑制できないために生じると述べている.

具体的に言語性保続の出現頻度に影響を与える要因 として，低頻度語ほど出現しやすい ${ }^{8-10)}$ ，相互に意味 的類似性が高いほど出現しやすい7,11,12) ことに関して は 3 報以上の実証データがあり，ほほ確かなことと考 えられる。一方, Santo Pietro ${ }^{8,10)}$, 石川ら ${ }^{12)}$ は, 刺激の提示時間間隔が影響するというデータを示して いるが（前者は 10 秒，後者は 15 秒で保続数が有意に 減少)，さらに調べる必要があると考える。また，他 の要因に関しては記述的な報告が多く，保続の減少に 結びつけるための十分な知見があるとはいいがたい.

本研究の目的は, 条件を統制した呼称課題を実施し, 失語症者の言語性保続減少のための基礎デー夕を得る ことである，本報告は，刺激の色情報の有無と刺激提 示間隔を操作して呼称課題を実施した研究 1 と, 刺激
提示間隔をより厳密に操作して呼称課題を実施した研 究 2 からなる。なお，本研究では保続は言語性保続を 指すものとする.

\section{研 究 1}

研究 1 では, 以下の仮説の下に呼称課題条件を統制 した。(1)保続が活性化不足で生じるのであれば，目標 語の活性化を促進する要因を操作することで保続が減 少すると考えられる，そこで，目標語の白黒線画に加 え, カラー写真を使用して課題を実施した。 色の入力 は意味情報との関連を強化して語彙へのアクセスを速 くすると考えられており ${ }^{13)}$ ，カラー写真を使用するこ とで目標語の活性化が促進されると考えた。(2)一方, 抑制不足によって保続が生じるのであれば，先行項目 の賦活を抑制する要因を操作することで保続が減少す ると考えられる，発話の賦活を抑制するためには，刺 激の提示間隔を延長することが考えられる ${ }^{8,10,12)}$ 。そ こで，刺激の提示間隔を操作して課題を実施した。(3) また近年，生物と非生物では概念的知識の構造が異な $り^{14,15)}$ ，カテゴリー特異性障害など，その違いが呼称 の成否や誤り方に影響を及ぼすことがしばしば指摘さ れている ${ }^{16,17)}$ ，そこで，目標語の意味カテゴリーも保 続の発生に関連する可能性があると考え，2種類のカ テゴリーから刺激を選択して課題を実施した。

\section{1. 方法}

1 ) 対象

脳血管疾患により失語を呈したもののうち, 以下の 取り込み基準を満たした 22 名（男性 14 名, 女性 8 名） である. (1)年齢が 85 歳以下, (2)発症後 1 力月以上経過, (3)明らかな感覚障害, 失語以外の著明な認知機能障害 がない, (4)標準失語症検査（以下 SLTA）の「呼称」 で無反応，自動言語以外の反応が 10/20 項目以上（ほ とんど発語を得られない重度の失語症者を除く).

対象の年齢は平均 $73.1 \pm 10.0$ 歳で, 教育年数は平均 $12.1 \pm 2.4$ 年, 発症からの月数は平均 $61.7 \pm 81.6$ 力月で あった。原因疾患は脳梗塞 15 名, 脳出血 6 名, くも 膜下出血 1 名で, 病巣は左半球損傷後に失語を生じた ものが 17 名, 左右両半球にわたる損傷後のものが 2 名, 不明が 3 名であった，失語型はブローカ 8 名，超皮質 性運動 1 名, ウェルニッケ 5 名, 超皮質性感覚 1 名, 伝導 1 名, 健忘 4 名, 非定型流暢性 2 名であった。 SLTAの「呼称」正答数は平均 $15.5 \pm 4.6$ であった. 
2 ) 刺激材料

生物として動物（哺乳類・鳥類）カテゴリーから 20 語, 非生物として道具カテゴリーから 20 語の計 40 語を選択した。 カテゴリーの範囲は失語症語彙検査 ${ }^{18)}$ を参考にした，語はすべて $2-4$ モーラ語で, NTTデー タベースシリーズ ${ }^{19)} に$ 基づき親密度を統制した，失 語症者においては反応が得られにくい低親密度語を除 き, 音声文字親密度に扮いて親密度 6.0 以上を高親密 度語，親密度 5.0 以上 6.0 未満を中親密度語とし, カ テゴリー間で平均親密度に差がないように, カテゴ リーごとにそれぞれ 10 語ずつ選択した。動物・道具 とも親密度は, 高親密度群で平均 6.2 , 中親密度語群 で平均 5.5 であった。目標語を表 1 に示す.

提示刺激として, すべての単語に対し白黒線画カー ドとカラー写真カードの 2 種類を用意した。白黒線画 カードは絵カード 2001 (エスコアール社) から選択し, カラー写真カードは白黒線画と似たアングルのものを フリー素材から選択した。

\section{3 ) 手続き}

図版を 1 枚ずつ提示し呼称を求めた。すべての条件 で, 40 項目の提示順序はランダムとした。 15 秒以内 の正反応を正答とし，正答が得られた時点または 15 秒を経過した時点で 1 試行が終了するものとした。試 行間は 1 秒または 10 秒の間隔を空け, その間は図版 を提示しなかった。

提示条件として, 眓版の色情報の有無と刺激の提示 間隔の組み合わせ計 4 条件を, 実施日 A（白黒線画 $\times 1$ 秒間隔，カラー写真 $\times 1$ 秒間隔），実施日 B (白黒 線画 $\times 10$ 秒間隔)，実施日 C (カラー写真 $\times 10$ 秒間隔） の 3 日間で実施した。実施日 A B B ・ C の試行順は被 検者間でランダムとした。また，実施日 A の 2 条件

表 1 研究 1 における目標語

\begin{tabular}{|c|c|c|}
\hline & 高親密度語 & 中親密度語 \\
\hline 動物 & $\begin{array}{l}\text { 犬, 牛, キリン, 熊, コ } \\
\text { アラ, 猫, 羊, 豚, ライ } \\
\text { オン, ラクダ }\end{array}$ & $\begin{array}{l}\text { イノシシ, ウサギ, キッ } \\
\text { ネ, 孔雀, 鹿, 鷹, タヌ } \\
\text { キ, チーター, 鶴, 山羊 }\end{array}$ \\
\hline 道具 & $\begin{array}{l}\text { 団扇, 鉛筆, 傘, タワシ, } \\
\text { 時計, 歯ブラシ, 包丁, } \\
\text { 眼鏡, ロウソク, やかん }\end{array}$ & $\begin{array}{l}\text { 椅子, 金づち, 缶切り, 釘, } \\
\text { 靴べら, 足袋, 爪切り, } \\
\text { はたき, 分度器, 棌の手 }\end{array}$ \\
\hline
\end{tabular}

表 2 研究 1 における親密度別の平均正答数および 平均保続数

\begin{tabular}{lrrrr}
\hline & 高親密度語 & 中親密度語 & $\mathrm{p}$ 值 \\
\hline 平均正答数 & $14.7(4.4)$ & $10.6(4.3)$ & $<0.01$ \\
平均保続数 & $1.0(1.7)$ & $1.7(2.0)$ & $<0.01$ \\
\hline & \multicolumn{4}{c}{ カッコ内は標準偏差 }
\end{tabular}

の実施順は被検者間でカウンターバランスをとり，条 件間の干渉を避けるため, 間に5 分の休憩を設けた.

各項目に対する被検者の最初の言語反応を分析し, 呼称の正答数と出現した保続数を集計した. 石川ら ${ }^{20)}$ を参考に，それ以前の発話と連続する 2 モーラ以上が 共通した発話をすべて保続と判断した。すなわち「と けい」と発話した以降の項目で「とけ」「けい」「とけ い」と発話したものを保続とし，「と」などは保続で ないとした。

\section{4 ）倫理的配慮}

本研究は倉敷平成病院倫理委員会の承認を得て実施 した（承認番号 H28-005）.

\section{2 . 結果}

1) 正答数

親密度別の平均正答数を表 2 に示す。高親密度語群 と中親密度語群間には有意差を認めた（対応のある 検定 : $\mathrm{t}(21)=10.52, \mathrm{p}<0.01)$ 。すなわち, 高親密度 語のほうが中親密度語よりも正答数が多かった。

カテゴリー (動物/道具), 色情報 (白黒線画/カラー 写真), 刺激提示間隔（1 秒間隔 $/ 10$ 秒間隔）別の平均 正答数を図 1 に示す. 反復測定 3 元配置分散分析では, 提示間隔に主効果を認めた $(\mathrm{F}(1,21)=5.84, \mathrm{p}<0.05)$. すなわち, 1 秒間隔に比べ 10 秒間隔で正答数が多かっ た. 一方, 他の主効果掞よび交互作用は認めなかった. すなわち，カテゴリーや色情報の違いによる正答数の 差は認めなかった。

\section{2 ) 保続数}

親密度別の平均保続数を表 2 に示す。高親密度語群 と中親密度語群間には有意差を認めた（対応のある 検定 : $\mathrm{t}(21)=-4.17, \mathrm{p}<0.01)$. すなわち, 中親密度 語のほうが高親密度語よりも保続数が多かった。

カテゴリー, 色情報, 提示間隔別の平均保続数を図 2 に示す, 反復測定 3 元配置分散分析では, カテゴリー

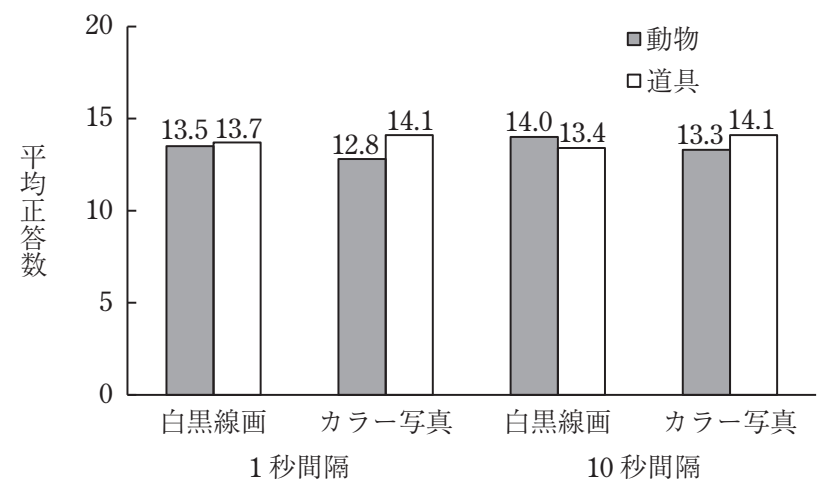

図 1 研究 1 における要因別の平均正答数 図中の数值は平均正答数. 


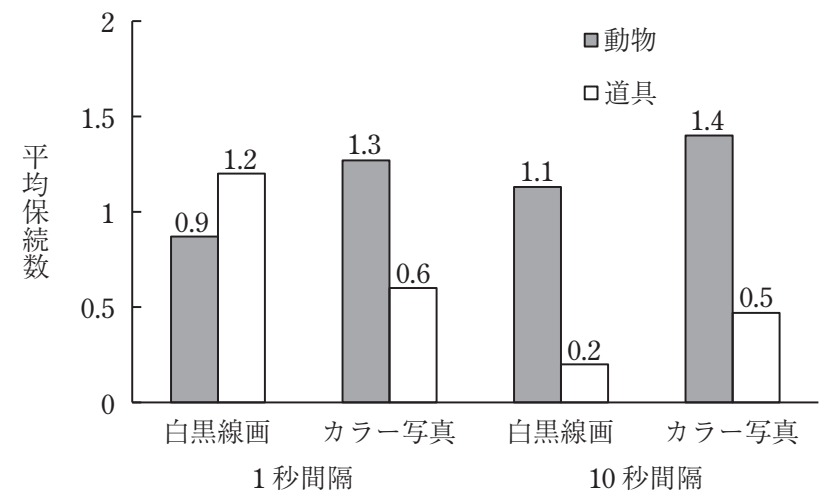

図 2 研究 1 における要因別の平均保続数 図中の数值は平均保続数.

の主効果を認めた $(\mathrm{F}(1,21)=6.54, \mathrm{p}<0.05)$. すな わち，動物のほうが道具に比べ保続数が多かった。一 方，色情報および提示間隔の主効果は認めなかった。 すなわち, これらの違いによる保続数の差は認めな かった。 また，カテゴリー×提示間隔の交互作用が有 意傾向であった $(\mathrm{F}(1,21)=3.92, \mathrm{p}=0.06)$. すなわち， 道具では 10 秒間隔になると保続数が減る傾向にあっ たが，動物ではそうでなかった。

\section{3. まとめ}

研究 1 では 3 点の結果が得られた。第 1 に, 保続の 出現には語の親密度が関連していた，第 2 に，語の親 密度が同等で正答数にも差がないにもかかわらず，道 具カテゴリーに比べ動物カテゴリーで保続は多く出現 した，第 3 に，道具カテゴリーに反し動物カテゴリー では刺激の提示間隔が長くても保続数が減少しなかっ た.

2 点目と 3 点目に関しては, 両カテゴリーにおける 概念的知識構造の違いによって説明することができる と考える，それぞれの項目の意味はより小さな複数の 意味属性からなっていると想定されているが5, 21)，一 般的に生物カテゴリーではカテゴリー内で共有される 意味属性が多く, 非生物カテゴリーではカテゴリー内 で共有される意味属性は少ないと考えられてい る ${ }^{14,15)}$ ，そうであれば，道具に比べて動物では先行す る意味属性の賦活が以降の発話に影響を与えやすく, 保続は出現しやすいと考えられる(詳細は後述)。こ のように，先行項目の賦活を抑制するために要す時間 はカテゴリーごとに異なる可能性が示唆され, 次の研 究を計画した。

\section{研 究 2}

研究 1 において, 先行項目の賦活を抑制するために
要す時間はカテゴリーによって異なる可能性が示唆さ れた。また研究 1 では, 動物カテゴリーにおいて刺激 提示間隔を延ばしても保続数は減少しなかった。この 一因として，提示間隔が 10 秒の際に，言えなかった 単語を引き続き考える被検者や，正答であったが自信 のなかった反応を反炰する被検者がおり，そのような 一部の被検者の行動が結果に影響を与えた可能性が考 えられた。

そこで研究 2 の目的は, 刺激の提示方法をより厳密 に操作して, 保続とカテゴリー, 提示間隔との関係を, さらに明らかにすることである。刺激提示をパソコン で制御し，提示間隔に 20 秒条件を追加するとともに， 試行間は前の発話の反すうを妨げるために非言語性干 渉課題の実施を求めた。な招, 研究 1 において保続と の関連が否定的であった色情報の要因は, 研究 2 では 除外した。

\section{1. 方法}

1) 対象

脳血管疾患により失語を呈したもののうち, 研究 1 と同じ以下の取り込み基準を満たした 28 名（男性 18 名，女性 10 名）である。(1)年齢が 85 歳以下，(2)発症 後 1 力月以上経過, (3)明らかな感覚障害, 失語以外の 著明な認知機能障害がない, (4) SLTAの「呼称」で 無反応, 自動言語以外の反応が $10 / 20$ 項目以上.

対象の年齢は平均 $71.3 \pm 10.5$ 歳で, 教育年数は平均 $11.6 \pm 2.2$ 年, 発症からの月数は平均 $47.7 \pm 66.0$ カ月で あった，原因疾患は脳梗塞 16 名, 脳出血 11 名, くも 膜下出血 1 名で, 病巣は左半球損傷後に失語を生じた ものが 25 名, 右半球損傷後が 1 名, 不明が 2 名であっ た。失語型はブローカ 8 名, 非定型非流暢性 1 名, ウ工 ルニッケ 7 名, 超皮質性感覚 1 名, 健忘 8 名, 非定型 流暢性 3 名であった．SLTAの「呼称」正答数は平均 $14.9 \pm 5.4$ であった。

\section{2 ) 刺激材料}

研究 1 と同様, 動物（哺乳類・鳥類）カテゴリーか ら 20 語, 道具カテゴリーから 20 語の計 40 語を選択 した，語はすべて $2-4$ モーラ語で，NTT データベー スシリーズ19)に基づき親密度を統制し，カテゴリー 間で平均親密度に差がないように，カテゴリーごとに 高親密度語と中親密度語をそれぞれ 10 語ずつ選択し た. 語の半数は研究 1 と同様のもの, 半数は新規のも のとした。動物の高親密度語は平均 6.3, 中親密度語 は平均 5.7 , 道具の高親密度語は平均 6.3 , 中親密度語 は平均 5.6 であった。目標語を表 3 に示す。

提示刺激として，すべての単語に対し白黒線画をパ 
表 3 研究 2 における目標語

\begin{tabular}{|c|c|c|}
\hline & 高親密度語 & 中親密度語 \\
\hline 動物 & $\begin{array}{l}\text { 馬, キリン, 熊, コアラ, } \\
\text { 鶏, 猫, 白鳥, パンダ, } \\
\text { もぐら, ライオン } \\
\text { 傘, 算盤, タワシ, ノコ } \\
\text { ギリ, ハサミ, バケツ, } \\
\text { 歯ブラシ, ほうき, やか } \\
\text { ん, ロウソク }\end{array}$ & $\begin{array}{l}\text { イノシシ, カラス, キツ } \\
\text { ネ, 孔雀, 猿, 鹿, 象, } \\
\text { ダチョウ, 虎, 山羊 } \\
\text { 金づち, 缶切り, 靴べら, } \\
\text { じょうろ, 爪切り, 長靴, } \\
\text { 箸, 分度器, ペンチ, ま } \\
\text { な板 }\end{array}$ \\
\hline
\end{tabular}

表 4 研究 2 における親密度別の平均正答数および 平均保続数

\begin{tabular}{lrrrr}
\hline & 高親密度語 & 中親密度語 & $\mathrm{p}$ 值 \\
\hline 平均正答数 & $13.0(5.4)$ & $11.4(5.5)$ & $<0.01$ \\
平均保続数 & $1.5(2.1)$ & $2.1(2.4)$ & $<0.01$ \\
\hline \multicolumn{5}{c}{ カッコ内は標準偏差 }
\end{tabular}

ソコンに取り达んだ. 研究 1 と同様, 白黒線画は絵カー ド 2001 （エスコアール社）から選択した.

3 ) 手続き

提示条件として, 刺激の提示間隔で 3 水準（1 秒間 隔 $/ 10$ 秒間隔 $/ 20$ 秒間隔）を設定し, 3 日間で実施した. 3 日間の実施順は被検者間でランダムとした。 パソコ ン画面に注視点を 1 秒間提示した後に, 図版を 1 枚ず つ提示し，呼称を求めた。すべての条件で，40 項目 の提示順序はランダムとした. 15 秒以内の正反応を 正答とし，正答が得られた時点または 15 秒を経過し た時点で 1 試行が終了するものとした，提示間隔が 10 秒または 20 秒条件の際は, 試行間に干渉課題の実 施を求め, 前の発話を反すうすることを妨げた.

干渉課題は以下のと抢りである。 パソコン画面に 1

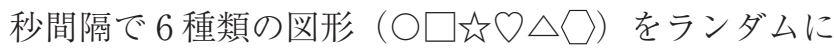
提示し，「々」が出現したらスペースキーを押すよう に求めた，干渉課題については，呼称課題とは別に事 前に説明と練習を行い，十分な理解が得られているこ とを確認した。

研究 1 と同じく, 各項目に対する被検者の最初の言 語反応を分析し，呼称の正答数と出現した保続数を集 計した，それ以前の発話と連続する 2 モーラ以上が共 通した発話をすべて保続と判断した。

\section{4）倫理的配慮}

本研究は倉敷平成病院倫理委員会の承認を得て実施 した（承認番号 H29-0011）。

\section{2. 結果}

\section{1 ) 正答数}

親密度別の平均正答数を表 4 に示す。高親密度語群 と中親密度語群間には有意差を認めた（対応のある $\mathrm{t}$

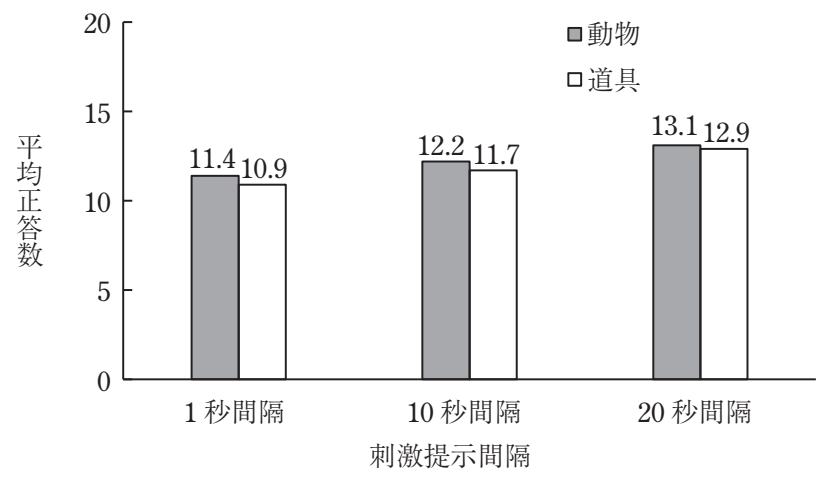

図 3 研究 2 における要因別の平均正答数 図中の数值は平均正答数.

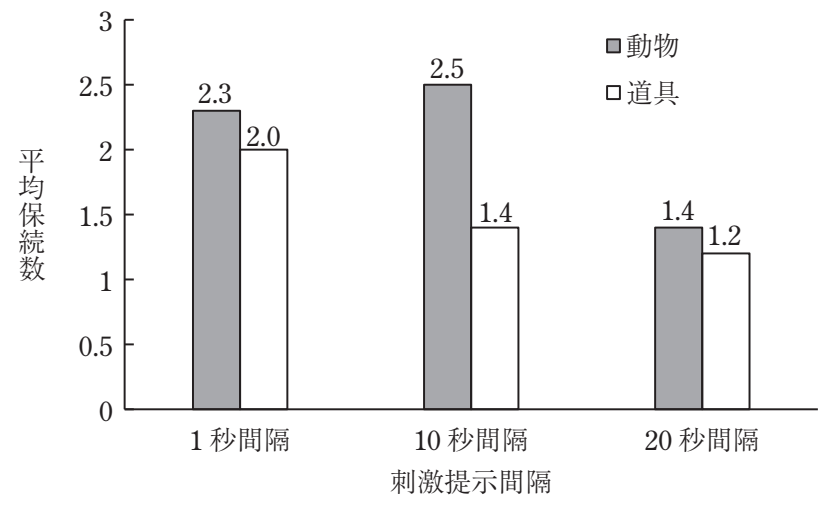

図 4 研究 2 における要因別の平均保続数 図中の数值は平均保続数.

検定 : $\mathrm{t}(27)=6.23, \mathrm{p}<0.01)$ ．すなわち，高親密度語 のほうが中親密度語よりも正答数が多かった。

カテゴリー (動物/道具), 提示間隔 (1 秒間隔/10 秒間隔 $/ 20$ 秒間隔）別の平均正答数を図 3 に示す. 反 復測定 2 元配置分散分析の結果, 提示間隔に主効果を 認めた $(\mathrm{F}(2,54)=12.57, \mathrm{p}<0.01)$. すなわち, 刺激 提示間隔が長くなるほど正答数は多かった。一方，力 テゴリーの主効果および交互作用は認めなかった。す なわち, カテゴリーの違いによる正答数の差は認めな かった.

2 ) 保続数

親密度別の平均保続数を表 4 に示す. 高親密度語群 と中親密度語群間には有意差を認めた（対応のある $\mathrm{t}$ 検定 : $\mathrm{t}(27)=-3.20, \mathrm{p}<0.01)$ ．すなわち，中親密度 語群のほうが高親密度語群よりも保続数が多かった。

カテゴリー, 提示間隔別の平均保続数を図 4 に示す. 反復測定 2 元配置分散分析では, カテゴリーの主効果 に差の傾向を認めた $(\mathrm{F}(1,27)=2.95, \mathrm{p}=0.097)$.す なわち，動物のほうが道具に比べ保続数が多い傾向に あった。また，提示間隔に主効果を認めた（F $(2,54)$ $=4.49, \quad \mathrm{p}<0.05)$ ．すなわち，提示間隔が長くなるほ 
ど保続数が減少した。 カテゴリー×提示間隔の交互作 用は認めなかった。ただし，それぞれの提示間隔にお ける保続数を対応のある $\mathrm{t}$ 検定で比較すると，1秒間 隔および 20 秒間隔では有意差を認めなかったが, 10 秒間隔では動物における保続数は道具よりも有意に多 かった（ $(27)=3.18, \mathrm{p}<0.01)$.

\section{3. まとめ}

研究 2 では 3 点の結果が得られた。第 1 に, 保続の 出現には語の親密度が関連していた。第 2 に, 語の親 密度が同等で正答数にも差がないにもかかわらず，道 具カテゴリーに比べ動物カテゴリーで保続は多く出現 した，第 3 に，刺激提示間隔による保続の減衰パター ンは動物カテゴリーと道具カテゴリーで異なってい た。両カテゴリーの保続数は, 10 秒間隔では差を認 めたが， 1 秒間隔および 20 秒間隔では差はなく，カ テゴリーごとに保続を抑制するために要す時間に違い があることが裏づけられた。

\section{総合考察}

本研究では, 研究 1 および研究 2 を通じて, 語の親 密度と保続の関連が認められ, Santo Pietro $5^{8,10)}$ や Martin $ら^{9)}$ の低頻度語ほど保続が出現しやすいとい う知見が再確認された。

研究 1 では, 先行研究における発現機序仮説に基づ き, カラー写真を使用して目標語の活性化を促進し, また刺激の提示間隔を延長して先行項目の賦活を抑制 した呼称課題を実施した。その結果, 刺激提示間隔と 保続の間に関連を認めた一方, 色情報と保続の間には 関連を認めなかった。このことは，刺激の提示間隔を 長くすることで，すでに表出した項目の賦活抑制が促 されたため保続が減少したものと考えられ， Yamadori ${ }^{6)}$ やAlbert $ら^{7)}$ が述べている, 保続の発現 に打ける抑制不足説を支持するものと考える. 研究 2 でも研究 1 と同様, 提示間隔と保続の関連が再現され, 抑制不足説がさらに支持できるものと考える.ただし， 色情報の提示だけが活性化を促進する手段ではない.
実際に, 今回の研究では色情報の提示によって正答数 の増加は認められず, 活性化を十分に促進できなかっ た可能性もある。したがって，本研究の結果から活性 化不足説を否定することはできないと考える.

また本研究では, 研究 1 , 研究 2 とも目標語の意味 カテゴリーと保続との関連が示された。動物カテゴ リーと道具カテゴリーで語の親密度は同等であり, カ テゴリーによって正答数に差は認められなかった，そ れにもかかわらず, 道具カテゴリーに比べ動物カテゴ リーで保続は多く出現した. McClelland ${ }^{21)}$ や Taylor

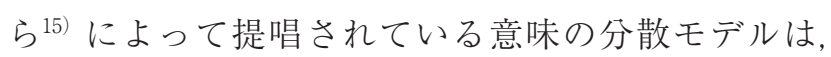
それぞれの項目の意味は複数の意味属性からなってい ると想定するものである。単語を表出する際は，まず 項目の意味情報が活性化され，それに対応する語彙・ 音韻が選択されると考えられている。一般的に, 生物 カテゴリーは非生物カテゴリーに比べ, 意味属性の数 が多く，またカテゴリー内で共有される意味属性が多 いと考えられている14,15). 例を図 5 に示す。「トラ」 を発語する際には，「呼吸をする」「見る」「目」など， 他の動物カテゴリー項目と共有される多くの意味属性 が賦活した状態になると考えられる。一方で道具カテ ゴリー内では,たとえば「ナイフ」と「コップ」と「血」 では形も色も機能も異なり, 共有される意味属性は少 ない，そのため，道具に比べて動物のほうが先行する 意味属性の賦活が以降の発話にも影響を及ぼしやす く，保続は出現しやすいものと考える.

本研究では, 動物カテゴリーと道具カテゴリーでは 保続の発生頻度が異なり，また保続を抑制するために 要す時間に違いがあることが示された。私たちが考察 したとおりそれが生物カテゴリーと非生物カテゴリー の意味属性分布の違いによるものだとしたら，臨床一 の示唆としては以下があるだろう。すなわち, 失語の 訓練プログラム立案の際には，保続が多く出現する患 者や保続の出現に対してストレスを感じている患者に 対しては, 訓練語のなかで生物カテゴリーの割合を減 らし, 生物カテゴリーの語の連続を避けるなど非生物

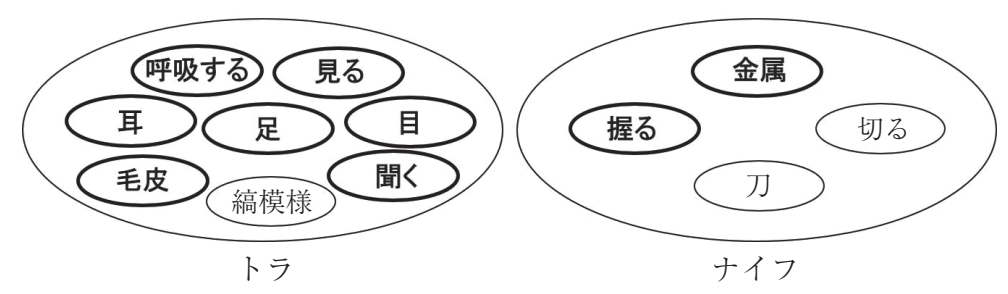

図 5 意味の分散モデル

Taylor ら ${ }^{15)}$ を基に筆者が作成. 太枠・ゴシックはカテゴリー内で共有さ れる意味属性. 
カテゴリーを中心とした訓練プログラムを提供する. また，特に生物カテゴリーを訓練するときは，刺激の 提示間隔を長めに確保することも有効だと示唆され る、そのことで保続発生を抑制し，患者に心理的負担 を与えない言語機能訓練が提供できるものと考える.

今後は, 動物と道具だけでなく他の意味カテゴリー の単語を用いた検討を行うことによって，保続に対す るカテゴリーや刺激提示間隔の影響をさらに明らかに する必要があると考える，また，日常生活場面で保続 を抑制する方法を検討することも必要であると考え る.

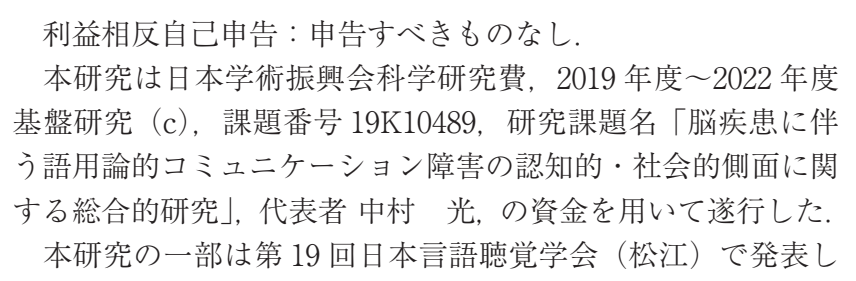

\section{文献}

1) Helm-Estabrooks N, Ramage A, Bayles KA, et al: Perseverative behavior in fluent and non-fluent aphasic adults. Aphasiology, 12: 689-698, 1998.

2) Martin N and Dell GS: Common mechanisms underlying perseverative and non-perseverative sound and word substitutions. Aphasiology, 21: 1002-1017, 2007.

3) Pilkington E, Keidel J, Kendrick LT, et al: Sources of phoneme errors in repetition: Perseverative, neologistic, and lesion patterns in jargon aphasia. Front Hum Neurosci, 11: 1-14, 2017.

4) Hirsh KW: Perseveration and activation in aphasic speech production. Cogn Neuropsychol, 15: 377-388, 1998.

5) Corbett F, Jefferies $E$ and Lambon Ralph MA: The use of cueing to alleviate recurrent verbal perseverations: Evidence from transcortical sensory aphasia. Aphasiology, 22: 363-382, 2008.

6) Yamadori A: Verbal perseveration in aphasia. Neuropsychologia, 19: 591-594, 1981.

7) Albert ML and Sandson J: Perseveration in aphasia.
Cortex, 22: 103-115, 1986.

8) Santo Pietro MJ and Rigrodsky S: The effects of temporal and semantic conditions on the occurrence of the error response of perseveration in adult aphasics. J Speech Hear Res, 25: 184-192, 1982.

9) Martin N and Dell GS: Perseverations and anticipations in aphasia: Primed intrusions from the past and future. Semin Speech Lang, 25: 349-362, 2004.

10) Santo Pietro MJ and Rigrodsky S: Patterns of oral-verbal perseveration in adult aphasics. Brain Lang, 29: 1-17, 1986.

11）宮崎泰広, 種村 純, 伊藤慈秀, 他 : 失語症例に扔ける言 語性保続の出現機序について. 高次脳機能研究, $23: 39-$ 46, 2003.

12）石川幸伸，藤田郁代：失語症患者における言語性保続の発 生に関係する要因の検討. 高次脳機能研究, 35：63-69, 2015.

13) Ines B, Filomena I and Luis F: The influence of color information on the recognition of color diagnostic and noncolor diagnostic objects. J Gen Psychol, 138: 49-65, 2011.

14) McRae K, de Sa VR and Seidenberg MS: On the nature and scope of featural representations of word meaning. J Exp Psychol Gen, 126: 99-130, 1997.

15) Taylor KI, Devereux BJ and Tyler LK: Conceptual structure: Towards an integrated neuro-cognitive account. Lang Cogn Process, 26: 1368-1401, 2011.

16) Devlin JT, Gonnerman LM, Andersen ES, et al: Categoryspecific semantic deficits in focal and widespread brain damage: A computational account. J Cogn Neurosci, 10: 77-94, 1998.

17) Gainotti G: The influence of gender and lesion location on naming disorders for animals, plants and artefacts. Neuropsychologia, 43: 1633-1644, 2005.

18）藤田郁代, 物井寿子, 奥平奈保子, 他 : 失語症語彙検查一 単語の情報処理の評価一，エスコアール，千葉，2000.

19）天野成昭, 近藤公久：(NTT データベースシリーズ）日本 語の語彙特性 第 1 巻 単語親密度, 三省堂, 東京, 1999 .

20）石川幸伸, 藤田郁代 : 失語症者における言語性保続の発現 機序の検討. 言語聴覚研究, 4:111-119, 2007.

21) McClelland JL: Putting knowledge in its place: A scheme for programming parallel processing structures on the fly. Cognitive Sci, 9: 113-146, 1985. 